\title{
32. SIGNIFICANCE OF TURBIDITES AT SITE 767 (CELEBES SEA) AND SITE 768 (SULU SEA) 1
}

\author{
C. Betzler, ${ }^{2,3}$ A. J. Nederbragt, ${ }^{4}$ and G. J. Nichols ${ }^{5}$
}

\begin{abstract}
The turbidite complexes drilled at Sites 767 and 768 are described and compared. In both cases the complexes are subdivided by sedimentary breaks that can be correlated with regional sedimentary cycle boundaries or regional unconformities. A comparison with the global sea-level chart shows that some breaks correspond to third-order cycles. Other cycle boundaries are obscured by tectonic activity in the area during the period of deposition. Most of the siliciclastic turbidites were derived from source areas rich in quartz detritus: detailed studies show that two source areas provided quartzose detritus to the Sulu Sea in the Miocene. In the Celebes Sea, volcanic source areas were also important source areas of terrigenous detritus. Turbidites of redeposited carbonate sediments occur in both basins.
\end{abstract}

\section{INTRODUCTION}

A number of different mechanisms are thought to affect the development of deep-water turbidite fan systems. According to Mitchum (1985), Mutti (1985), Shanmugam et al. (1985), Posamentier and Vail (1988), and Shanmugam and Moiola (1988), the development of these systems is greatly favored by lowstands of the sea level. Other authors, e.g., deVries Klein (1984), Gorsline (1984), Stow (1985), and Stow et al. (1985), assume that the tectonic setting exerts a first-order control on turbidite and fan development. A third important factor is the supply of sediment that may be controlled by the interaction of climatic and tectonic influences (e.g., Stow et al., 1985; Gorsline, 1984; Jervey, 1988; Kolla and Macurda, 1988).

The Sulu and Celebes Sea basins are partly age-equivalent but had different tectonic histories in the Neogene. Coeval turbidites within these two basins can be compared to determine the controls on turbidite sequences. During the Neogene both basins were bordered by terranes of continental basement and both active and inactive volcanic arcs. Changes in the nature and volume of material supplied to the basins from these surrounding areas can be assessed by examination of the petrography of the arenites in the turbidite deposits.

\section{SITE SETTING}

The east Eurasian margin is characterized by a series of marginal seas bordered by island arcs, for example the Banda, Celebes, and Sulu Seas. The basaltic basement of the Celebes Sea was formed in an open ocean setting during the middle Eocene while the Sulu Sea originated in the early Miocene as a back-arc or intra-arc basin (Rangin, 1989; Rangin et al., 1989).

The Celebes Sea Basin is partly enclosed by arc terranes, namely the Sulu Ridge to the northwest and the Sulawesi/ Sangihe arc to the south and east. The Tertiary Mindanao

\footnotetext{
${ }^{1}$ Silver, E. A., Rangin, C., von Breymann, M. T., et al., 1991. Proc. ODP, Sci. Results, 124: College Station, TX (Ocean Drilling Program).

2 Institut u. Museum für Geologie u. Paläontologie, Sigwartstr. 10, D-7400 Tübingen, Federal Republic of Germany.

${ }^{3}$ Present affiliation: Geologisch-Paläontologisches Institut, Senckenberganlage 32-34, 6000 Frankfurt/Main 11, Federal Republic of Germany.

${ }^{4}$ Instituut voor Aardwetenschappen, Vrije Universiteit, P.O.V. 7161, 1007 MC Amsterdam, The Netherlands.

${ }^{5}$ Department of Geology, Royal Holloway and Bedford New College, University of London, Egham, Surrey, TW20 0EX, United Kingdom.
}

orogene borders the basin to the northeast and to the southwest the basin is limited by the Mesozoic accretionary terrane of northeastern Borneo. The floor of the Celebes Sea is formed by an abyssal plain at depths of $4990-5400 \mathrm{~m}$ (Mammerickx et al., 1976). Two sites were drilled in the Celebes Sea, Site 767 and Site 770 (Fig. 1). Site 767 lies in a small sub-basin in a deep part of the basin floor $(4905 \mathrm{~m})$. The core recovery at this site varies from $40 \%$ to $98 \%$. Site 770 is located on a raised basement fault block $(4516 \mathrm{~m})$ with a condensed sedimentary section. Continuous coring at this site was restricted to the lower part of the section and no siliciclastic turbidites were recovered.

The Sulu Sea lies between Borneo and the Philippine Archipelago. To the southeast it is separated from the Celebes Sea by the Sulu Ridge. To the northwest the Palawan Islands separate the Sulu Sea from the South China Sea. A northeastsouthwest bathymetric high, the Cagayan Ridge, divides the Sulu Sea into two basins, the northwest and the southeast Sulu Sea basins. The southeast basin is up to $5575 \mathrm{~m}$ deep (Mammerickx et al., 1976) and is characterized by a thick crust overlain by a thick layer of sediments (Mascle and Biscarrat, 1978). Three holes were drilled in the southeast basin of the Sulu Sea: Sites 768, 769, and 771 (Fig. 1). Siliciclastic turbidites were only recovered at Site 768 , which was drilled at a water depth of $4395.3 \mathrm{~m}$. This site lies in the center of the southeast Sulu Sea on a flat abyssal plain $50 \mathrm{~km}$ to the southeast of the Cagayan Ridge. This plain pinches out to the northeast where it is in places bordered by southeastfacing, tilted fault blocks (Kudrass et al., 1989). Site 768 is located $10 \mathrm{~km}$ from the south-eastern axial termination of one of these blocks: the average core recovery at this site was $69.5 \%$. Sites 769 and 771 lie in shallower water on the flank of the Cagayan Ridge.

\section{DESCRIPTION AND INTERPRETATION OF THE TURBIDITE COMPLEXES}

\section{Database and Descriptive Terminology}

The information on bed thickness, sedimentary structures, and grain size are based on the visual core description and smear-slide examinations made on board ship. The petrography of the arenaceous material has been qualitatively assessed by the examination of grain mounts made of very fine and fine sand separated from the turbiditic sediments (63- to $177-\mu \mathrm{m}$ sieve fraction). 


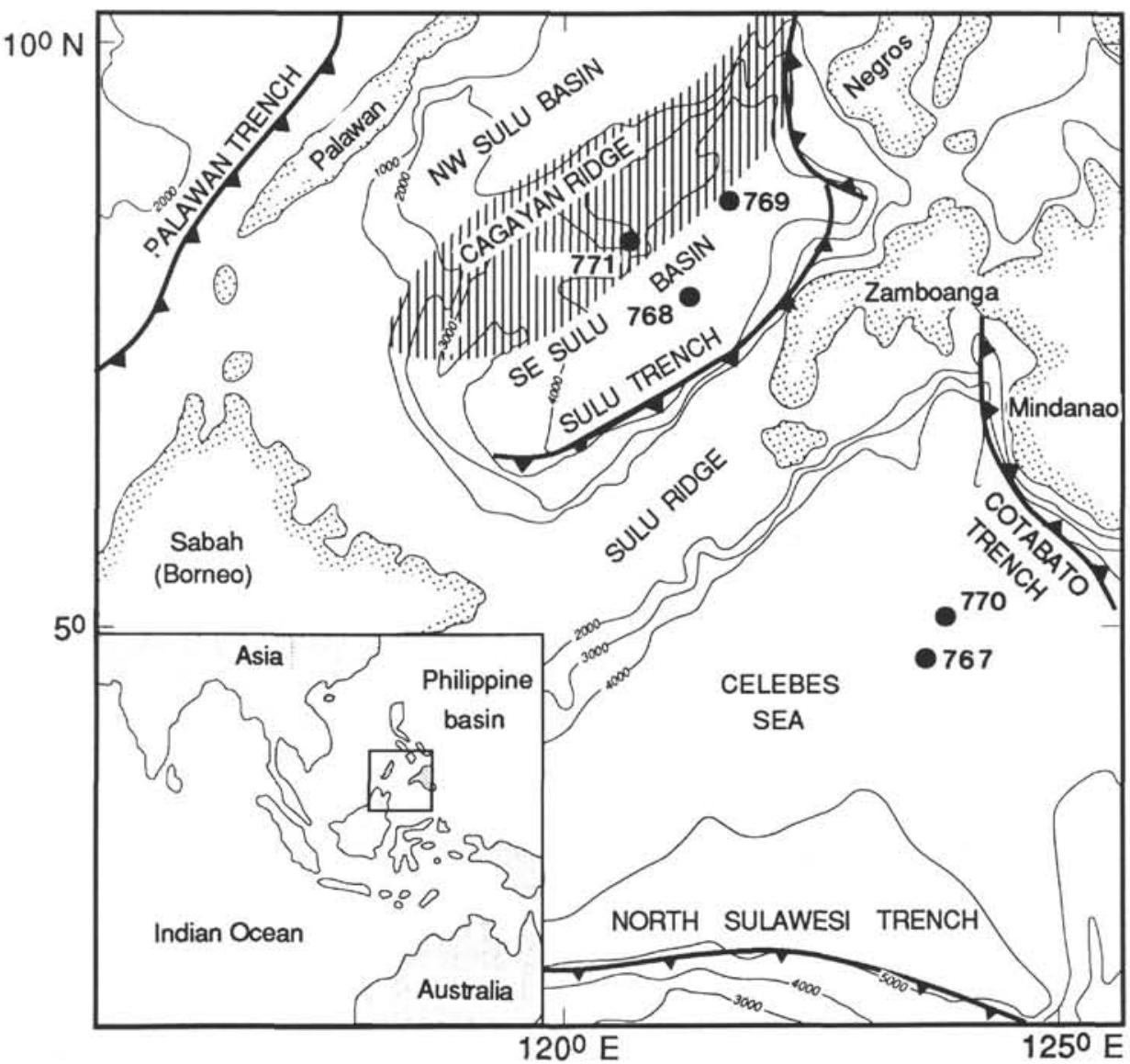

Figure 1. Location map of the drill sites of Leg 124.

The turbidites are classified using the Bouma (1962) classification scheme (Ta-Te). For fine-grained mud and silt turbidites which contain only Bouma Td and Te intervals the Stow and Piper (1984) classification scheme has been additionally used to allow further subdivision into T1-T8 and P (pelagic or hemipelagic) intervals.

\section{Terminology of Facies}

The most widely used facies classification for deep-water siliciclastic sediments is that of Mutti and Ricci Lucchi (1972, 1975) and Mutti (1977), summarized in Mutti (1979). The different facies are defined according to the sand/mud ratio, the thickness of the beds, the grain size, the geometry of the stratification surfaces, and the internal depositional structures. Modifications and amplifications of this facies scheme have been proposed by other authors (e.g., Stow, 1985; Pickering et al., 1989). These authors additionally subdivide the different facies classes e.g., into disorganized and organized facies groups.

\section{Description, Site 767}

At Site 767, deposition of siliciclastic and carbonate turbidites started in the middle to late Miocene (Zone NN8) and ended during the Pleistocene (NN20) (Fig. 2). During the late Miocene (NN10 and NN11) and Pliocene (NN15-NN18) numerous carbonate turbidites were deposited in the basin. The terrigenous turbidites have been divided into three "turbidite systems" that together form a "turbidite complex" (Mutti and Normark, 1987) (Fig. 2). The first (system A) is of early to middle Miocene age and was derived from a mixed volcanogenic and quartzose source area. It overlies brown pelagic clays belonging to the radiolarian Lychnocanoma elongata Zone or the Cyrtocapsella tetrapera Zone (early Miocene). System B is of middle Miocene to early Pliocene age (NN8- NN14) and is also derived from a mixed source area, although quartz-rich detritus dominates the lower part of the system. System C is early/middle Pliocene to Pleistocene in age (NN15-NN19) and is composed of material from a volcanic source area.

\section{System A}

Turbidite system A represents the first terrigenous influx at Site 767. It overlies brown pelagic claystone with a gradational contact. This turbidite system is $11.5 \mathrm{~m}$ thick (Cores 124767B-73X-124-767B-74X; 684.9-694.6 mbsf) (Fig. 3). It is made up of a succession of thin-bedded (up to $10 \mathrm{~cm}$ ) graded layers displaying ripple and planar lamination; sedimentary structures indicate that these beds are base-missing Tc-e turbidites. The grain size shows a general coarsening-upward trend from silty claystone to siltstone (Fig. 2) with the exception of the topmost layers of system $\mathrm{A}$, which are fine silty claystone. The sand-grade material in these turbidites is a mixture of plagioclase feldspar, quartzose lithic grains, and other rock fragments, rare biotite and heavy minerals.

\section{System B}

Turbidite system B is $364 \mathrm{~m}$ thick (Cores 124-767B-29X-124767B-68X; 271- 639 mbsf). Based on the grain-size distribution, the composition of the turbidites, and variations in bed thickness, five different turbidite stages are recognized (Fig. 2).

Stage 1 (Cores 124-767B-62X-124-767B-68X; 588-639 mbsf) is characterized by a succession of turbidites that both 

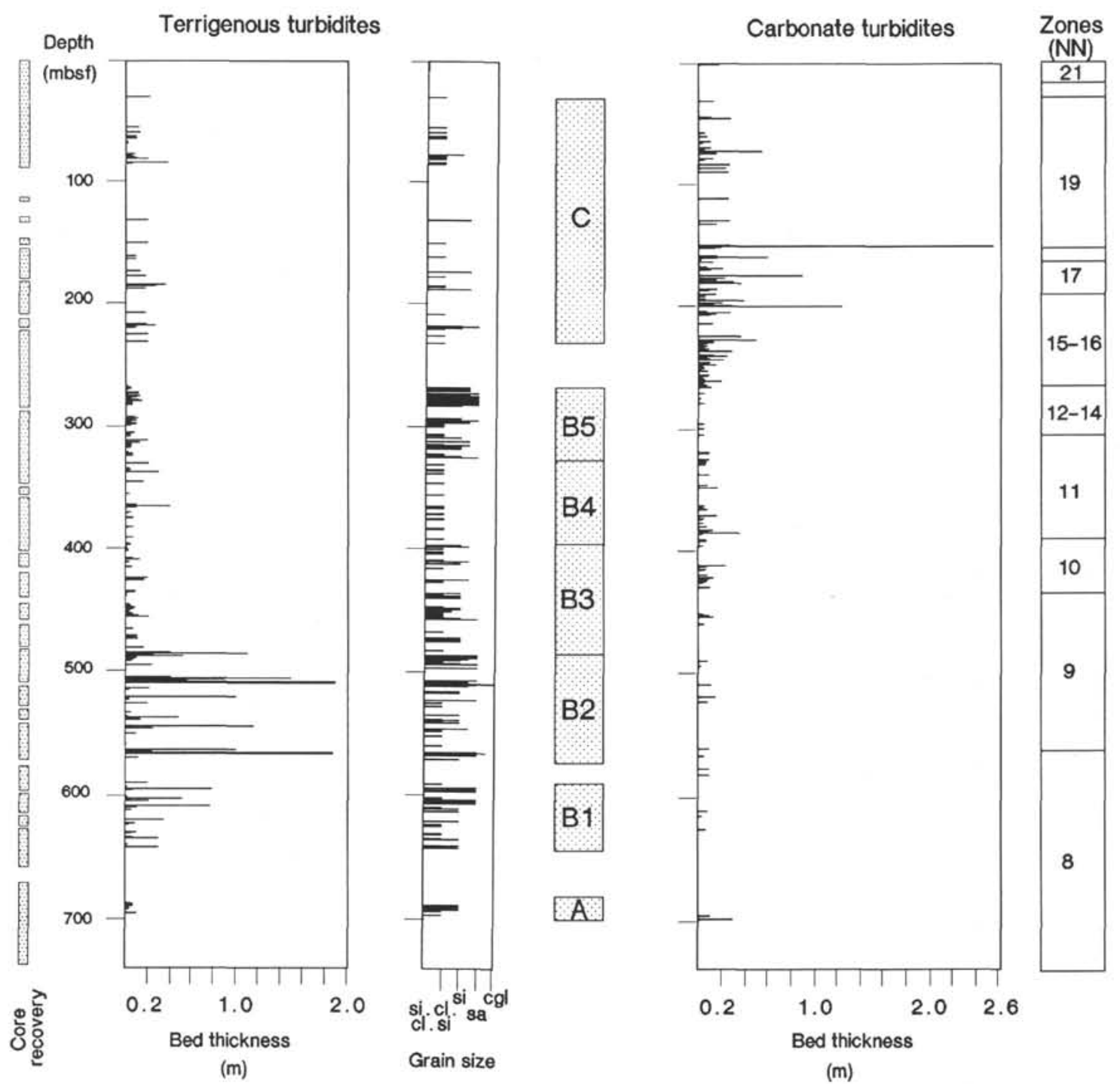

Figure 2. Turbidite systems, bed thickness distribution, and grain-size distribution of terrigenous turbidites at Site 767 , and bed thickness distribution of carbonate turbidites at Site 767. (Key: si.cl. and cl.si.: silty clay and clayey silt; si: silt; sa: sand; cgl: conglomerate.)

thicken and coarsen upward. The average thickness of the beds is $30 \mathrm{~cm}$ but single beds can be up to $100 \mathrm{~cm}$ thick. The grain size ranges from sand to silty clay. Coarser grained layers usually display planar lamination (Td-e rhythms), and a few beds within the upper part of stage 1 (Cores 124-767B-62X and 124-767B-63X) show ripple laminations (Tc-e rhythms). The sand is typically composed of quartz, quartzose lithic grains, and other rock fragments plus plant material.

Stage 2 is $84 \mathrm{~m}$ thick (Cores 124-767B-52X-124-767B$60 \mathrm{X} ; 484.4-568 \mathrm{mbsf}$ ) and consists of thin to thick beds (up to $200 \mathrm{~cm}$ thick). The basal unit of this turbidite stage (Core 124-767B-60X) is formed by a succession of medium-bedded turbidites (Td-e) made up of quartz grains, lithic fragments and plant debris. A $200 \mathrm{~cm}$ thick fining-upward sandstone to siltstone rhythm in the lower part of this stage contains abundant quartz, plant fragments, claystone clasts, and a calcareous faunal assemblage that suggests a relatively shallow source area. The remainder of stage 2 is characterized by an alternation of thin- and thick-bedded turbidites that are also composed of similar quartz-rich detritus with plant fragments and rare biotite, chlorite, tourmaline, and other heavy minerals. The grain size shows a general coarsening-upward trend, but the turbidites are not arranged in a megasequence pattern. Figure 4 shows a typical succession for the upper part of this stage; it consists of an alternation of thick-bedded sand to silt rhythms (Ta-e and Tb-e) and a thick undisturbed claystone intercalation with thin-bedded sand to silt rhythms.

Stage 3 is $77.9 \mathrm{~m}$ thick (Cores 124-767B-44X-124-767B51X: 406.5-484.4 mbsf). The lower limit of this stage corresponds to the boundary between the thin- to thick-bedded turbidites of Stage 2 and a succession made up of an alternation of claystones and graded, thin-bedded (up to $10 \mathrm{~cm}$ ) siltstone, clayey siltstone, and silty claystone beds. There is a distinct change in the petrology of the material from stage 2 to stage 3: quartz is rare or absent in sand composed mainly of rock fragments (which include chert), rare feldspar and biotite mica. The siltstone layers show the characteristics of Tc-e and Td-e rhythms and the finer grained layers can be defined as T3 to P sequences (sensu Stow and Piper 1984). 


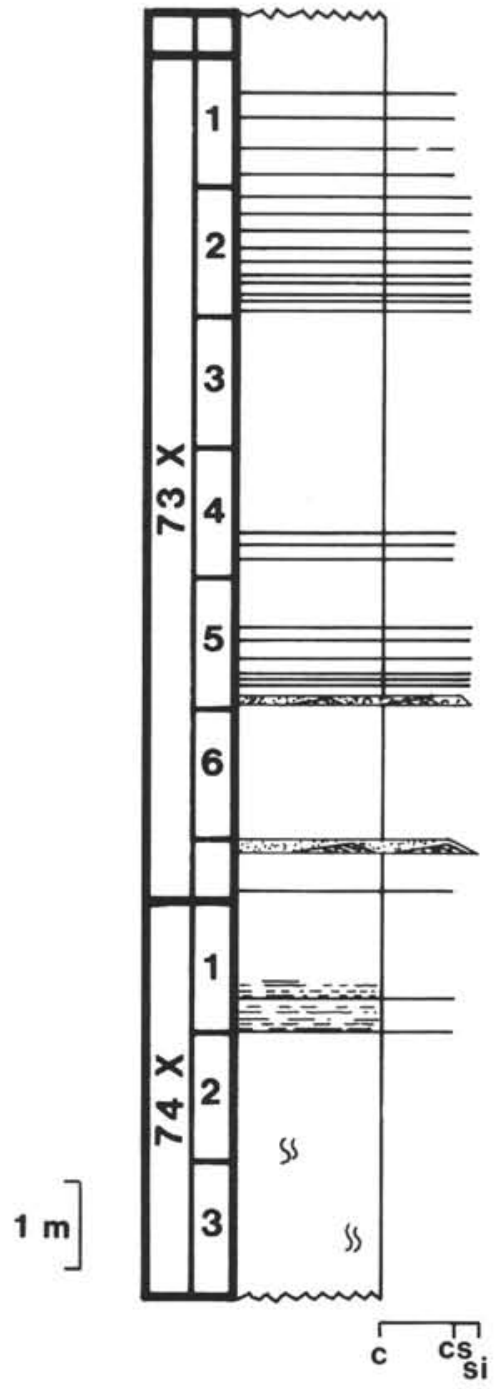

Figure 3. Turbidite system A, Site 767 (Cores 124-767B-73X and $-74 \mathrm{X}$ ). See text for explanation. (c: clay; cs: clayey silt; si: silt.)

Stage 4, which is $81.5 \mathrm{~m}$ thick (Core $124-767 \mathrm{~B}-35 \mathrm{X}$ to 124-767B-43X; 325 to $406.5 \mathrm{mbsf}$ ), consists of thin- to thickbedded silty clay and mud turbidites (Td-e, T4-P) which are of similar composition to those of stage 3. Structureless thick silty clay to clay rhythms with faint planar lamination at the base within the lower part of this stage may represent very fine-grained turbidite deposits similar to those described from the Mediterranean Sea by Stanley and Maldonado (1981).

Stage 5 is $59 \mathrm{~m}$ thick (Cores 124-767B-29X to 124-767B$35 \mathrm{X} ; 266-325 \mathrm{mbsf}$ ) and consists of a succession of thin- to medium-bedded sand to silt turbidites (Tc-e, Td-e). The turbidites in this stage are of the same composition as those of stages 3 and 4 and similarly are not arranged into megasequences.

\section{System C}

Turbidite system C is $206 \mathrm{~m}$ thick (Cores 124-767B-4H124-767B-26X; 31-237 mbsf) (Fig. 2). It is made up of an alternation of clay, silt, silty clay, and clayey silt layers up to $30 \mathrm{~cm}$ thick (Td-e). This system does not show any consistent variations in grain size and the beds are not arranged into megasequences. Feldspar grains and rock fragments are the principal constituents, with common biotite, hornblende, epi-

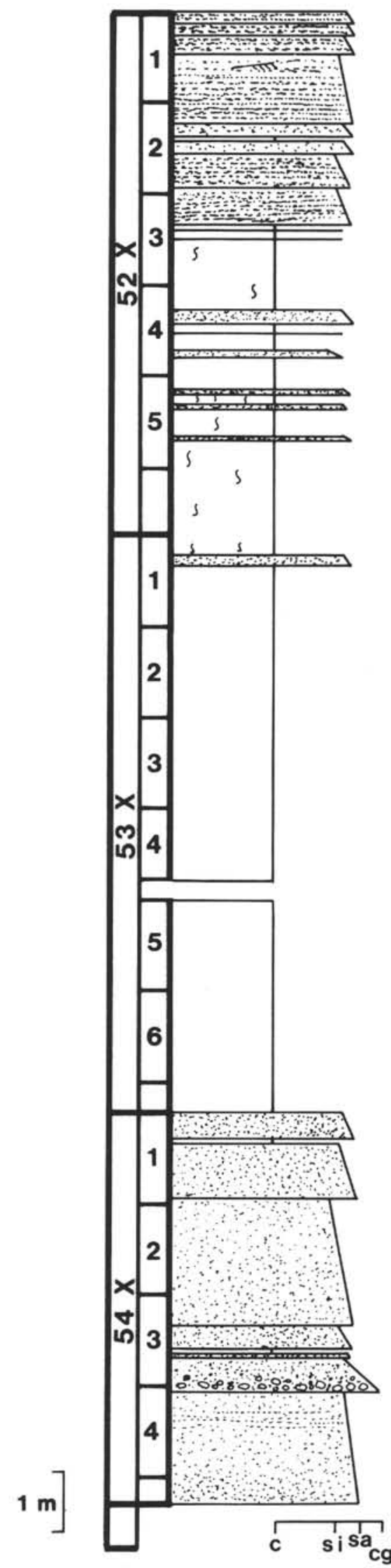

Figure 4. Upper part of turbidite system B2, Site 767 (Cores 124-767B$52 \mathrm{X},-53 \mathrm{X}$, and $-54 \mathrm{X}$ ). (c: clay; si: silt; sa: sand; cg: conglomerate.) 
Table 1. Sedimentary structures and turbidite facies, Site 767.

\begin{tabular}{|c|c|c|c|c|c|c|}
\hline \multirow{2}{*}{$\begin{array}{l}\text { Systems } \\
\text { Site } 767\end{array}$} & \multirow[b]{2}{*}{ Description } & \multirow{2}{*}{$\begin{array}{c}\text { Bouma } \\
1962\end{array}$} & \multirow{2}{*}{$\begin{array}{c}\text { Stow \& Piper } \\
1984\end{array}$} & \multicolumn{3}{|c|}{ Facies } \\
\hline & & & & $\begin{array}{l}\text { Mutti } \\
1979\end{array}$ & $\begin{array}{l}\text { Stow } \\
1985\end{array}$ & $\begin{array}{c}\text { Pickering et al } \\
1989\end{array}$ \\
\hline C & $\begin{array}{l}\text { thin to medium } \\
\text { bedded with faint } \\
\text { planar lamination } \\
\text { silty clays to silts }\end{array}$ & $T d-e$ & & D2-D3 & D2 & D2 \\
\hline 5 & $\begin{array}{l}\text { thin to medium } \\
\text { bedded with planar } \\
\text { and ripple lamination } \\
\text { silts to sands }\end{array}$ & $T d-e$ & & $D 2-D 3$ & D2-E2 & D2-E2 \\
\hline 4 & $\begin{array}{l}\text { thin to thick bedded } \\
\text { with faint planar } \\
\text { lamination } \\
\text { muds to silty clays }\end{array}$ & $T d-e$ & T4-P & D2-D3 & D2-E2 & $\begin{array}{l}\text { D2-E2 } \\
\text { E1.1 }\end{array}$ \\
\hline 3 & $\begin{array}{l}\text { thin bedded with } \\
\text { faint planar and } \\
\text { ripple lamination } \\
\text { silty clays to sitts }\end{array}$ & $T c-e, T d-e$ & T3-P & D2-D3 & D2-E2 & D2-E2 \\
\hline $1-2$ & $\begin{array}{l}\text { thin to thick bedded } \\
\text { with planar and } \\
\text { ripple lamination } \\
\text { silts to sands }\end{array}$ & $\begin{array}{l}T \text { a-e, T b-e } \\
T \text { c-e, T d-e }\end{array}$ & & D1-C2 & $\mathrm{C} 2$ & $\mathrm{C} 2.1-\mathrm{C} 2.3$ \\
\hline A & $\begin{array}{l}\text { thin bedded with } \\
\text { ripple and planar } \\
\text { lamination } \\
\text { silty clays to silts }\end{array}$ & $T c-\theta$ & & D3-D2 & D2 & D2. 1 \\
\hline
\end{tabular}

dote and other heavy minerals: volcanic glass, sponge spicules and radiolarian tests are common in the upper part of this system (above $150 \mathrm{mbsf}$ ).

\section{Interpretation}

The thin-bedded turbidites of system A show the characteristics of D3 to D2 facies of Mutti (1979) (Table 1). This facies is defined as one in which the sandy or silty interval within the turbidite beds is thinner than the pelitic interval. Stow (1985) also refers to this facies as D2 and in the Pickering et al. (1989) classification, system A would be considered to be facies D2.1 (graded-stratified silt).

The deposits of the lower part of turbidite system B are interpreted as facies C2 to D1 of Mutti (1979), C2 facies of Stow (1985), or C2.1 to C2.3 facies of Pickering et al. (1989). This facies consists of well defined sand or silt to clay intervals with complete Bouma sequences or as base-missing Bouma sequences. The deposits of stages 1 and 2 of system B are dominated by quartz and plant material and clearly have a different provenance to those of the upper part of this system, which came from a more mixed source made up of rock fragments, chert, and some volcanic material. The thinnerbedded and finer grained succession of the upper part of system B indicates D2 to D3 facies sensu Mutti (1979) or D2 to E2 facies (organized muds) according to Stow (1985) and Pickering et al. (1989). The thick unorganized muds and silty clays of system B (stage 4) would represent E1.1 facies of Pickering et al. (1989). These deposits usually form by rapid deposition resulting from ponding of mud-rich turbidity currents in confined basins (Pickering et al. 1989). System C shows the characteristics of the D3 to D2 facies of Mutti (1979) or D2 facies of Stow (1985) and Pickering et al. (1989).

As a whole, the facies of the turbidite complex at Site 767 indicate deposition in a basin plain to fan fringe setting. The sandy to gravelly layers of stage 2 of turbidite system B probably represent distal channel-fill and lobe sediments of a poorly efficient fan (Mutti 1979) corresponding to a type II system (Mutti 1985). According to Mutti's (1985) model, the thinner-bedded deposits would be lobe fringe to basin plain deposits within a type III system. Within these systems, small sandstone-filled channels develop in the proximal areas while basinward mudstones and silty sandstones are deposited. Site 767 was probably located in the basinward part of such a system. These sediments were derived from a source area rich in quartzose material and where there was abundant vegetation. A change in the source area is indicated by the virtual absence of quartz grains and the presence of chert in these sediments.

\section{Carbonate Turbidites}

Graded carbonate-rich beds occur throughout the whole section at Site 767. They are abundant in the late Pliocene section and consist of thin- to thick-bedded (up to $255 \mathrm{~cm}$ ) graded foraminifer and nannofossil oozes. The sedimentary structures present are planar, ripple and convolute lamination. The sand-sized fraction of samples from late Miocene to Pleistocene carbonate turbidites was examined to trace changes in the energy level and/or source of the material. To this purpose, samples were washed over a $63-\mu \mathrm{m}$ sieve screen. The general faunal content is described in Nederbragt (this volume). In addition, the relative frequencies of planktonic and benthic foraminifers were estimated. In autochthonous sediments, the benthic faunal composition is related to depth of deposition, and is the ratio of planktonic/benthic foraminifers (Wright, 1977; Van Marle et al., 1987). In turbidites, these variables may give some indication of the depth of source. Kuhn and Meischner (1988) used plankton percentages in turbidites to distinguish between slope or shelf-derived material. However, size and shape sorting during the transport will alter the faunal composition. The globular planktonic foraminifers would generally be easier to transport than benthic foraminifers. High planktonic frequencies could occur in turbidites from a deep water origin as well as in distal ones. Therefore, the estimated frequencies will also reflect changes in the energy level that the turbidite represents. To evaluate the importance of both signals, the frequencies are compared to the frequency and thickness of the turbidites (Fig. 2) and to qualitative estimates of the amount of skeletal debris, the size 
range of the foraminifer tests, and the size of the sand residues (Fig. 5).

The foraminifer faunas (Fig. 6) show a mixed depth signal. Most samples contain benthic foraminifers from a wide range of depth habitats. The epiphytic discorbids, which are derived from shallow water, occur together with deeper elements (e.g., common cassidulinids). However, long-term shifts in all frequencies indicate changes in the relative importance of shallow and deep material. The main change in the turbidite composition occurs around Core 124-767B-31X (Figs. 2, 5, and 6). Cores 124-767B-57X-124-767B-46X (late Miocene, Zone NN9) and Cores 124-767B-31X-124-767B-13X (Pliocene to Pleistocene, Zones NN19-NN12) contain frequent benthic foraminifers and relatively more discorbids than the samples from the other intervals (Fig. 6). The samples from these cores also contain varying amounts of skeletal debris, which is mainly derived from shelf-dwelling organism. This would indicate that the turbidites of these two intervals originated on a shelf area. The thin and relatively rare carbonate turbidites of the lower interval of Cores 124-767B-57X-124-767B-46X would be more distal than the thick and frequent carbonate turbidites of Cores 124-767B-31X-124-767B-13X (Fig. 2). This is reflected in the frequencies of planktonic foraminifers, which are higher in the lower interval (Fig. 6).

The large amounts of planktonic foraminifers found in the distal turbidites of the upper part of the upper Miocene (Cores 124-767B-45X-124-767B-32X) and the upper Pleistocene (Cores 124-767B-12X-124-767B-2H) are interpreted to reflect both an increase in the importance of deeper derived material (outer shelf and slope) and more extensive shape sorting.

\section{Description, Site 768}

At Site 768 deposition of siliciclastic turbidites started during the middle Miocene (NN5) and ended during the Pliocene (NN18-NN19). Deposition of scattered carbonate turbidites started during the middle Miocene and are abundant in the Pleistocene and Holocene succession. The turbidite complex at Site 768 is subdivided into three turbidite systems (Fig. 7). The first (system A, NN5-NN8) includes thickbedded deposits of quartz-rich gravel and sand. The second (system B, NN9-NN10) is made up of thin- and thick-bedded layers that can be distinguished as coming from two different source areas. The third (system C, NN11-NN18) consists of a succession of thin bedded turbidites with rare thicker beds, all derived from quartz-rich source terranes.

\section{System A}

System A (Cores 124-768C-38R-124-768C-42R, 713-758.5 mbsf) is formed by a succession of thin- to thick-bedded sandy turbidites (Tb-e, Tc-e and Td-e). The bed thickness ranges between 10 and $250 \mathrm{~cm}$. Quartz grains and lithic fragments of quartz-rich rocks with some feldspars, biotite, and heavy minerals are the main constituents of the sands in this system.

\section{System B}

This 358-m thick system (Cores 124-768C-2R-124-768C$38 \mathrm{R}$ ) is characterized by a bimodal bed thickness distribution (Fig. 7). The succession consists of thin-bedded turbidites with intercalations of thicker beds (up to $294 \mathrm{~cm}$ ). Grain size ranges from silty clay in the thin-bedded turbidites to coarse sand within the thicker beds.

Figure 8 shows a typical interval of the thin-bedded turbidite facies. It is characterized by 5 to $10 \mathrm{~cm}$ (in some cases $20 \mathrm{~cm}$ ) thick silty claystone to claystone rhythms. Dark-gray silt is concentrated in the lower part of the beds in a 1- to 2-cm-thick layer (Fig 8B); planar lamination is the only sedimentary structure observed and only occurs in a few beds.

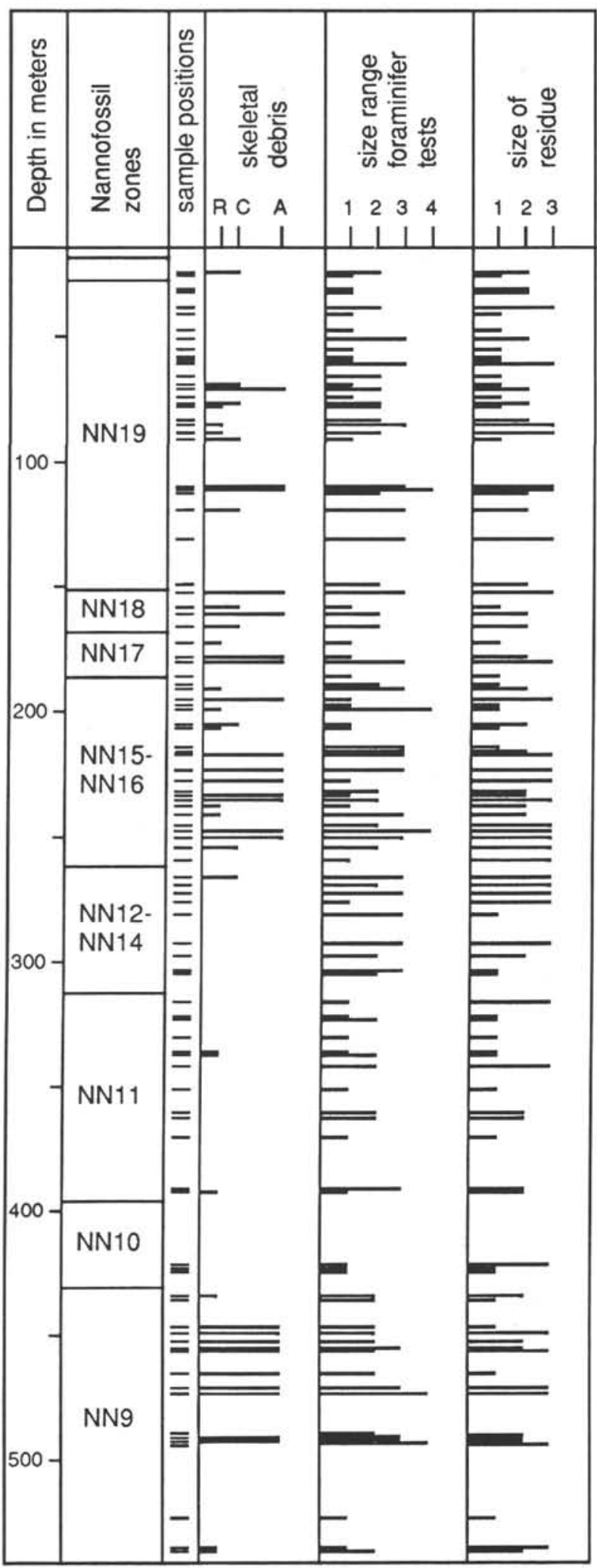

Figure 5. Qualitative estimates of amounts of skeletal debris, size range of foraminifer tests, and size of the sand-sized residues in samples from carbonate turbidites, Site 767. For skeletal debris: $\mathrm{R}=$ rare; $\mathrm{C}=$ common; $\mathrm{A}=$ abundant. Size ranges of foraminifer tests vary between small tests only (1) and the full range of test sizes expected in a foraminifer population (4). Categories 1 and 2 fall within a $63-m-125-m$ size range. Size of residue varies between small (1), with rare sand-sized particles in a $10-\mathrm{cm}^{3}$ sample, to large (3), from $10-\mathrm{cm}^{3}$ samples that yielded up to $1 \mathrm{~cm}^{3}$ of residue. 


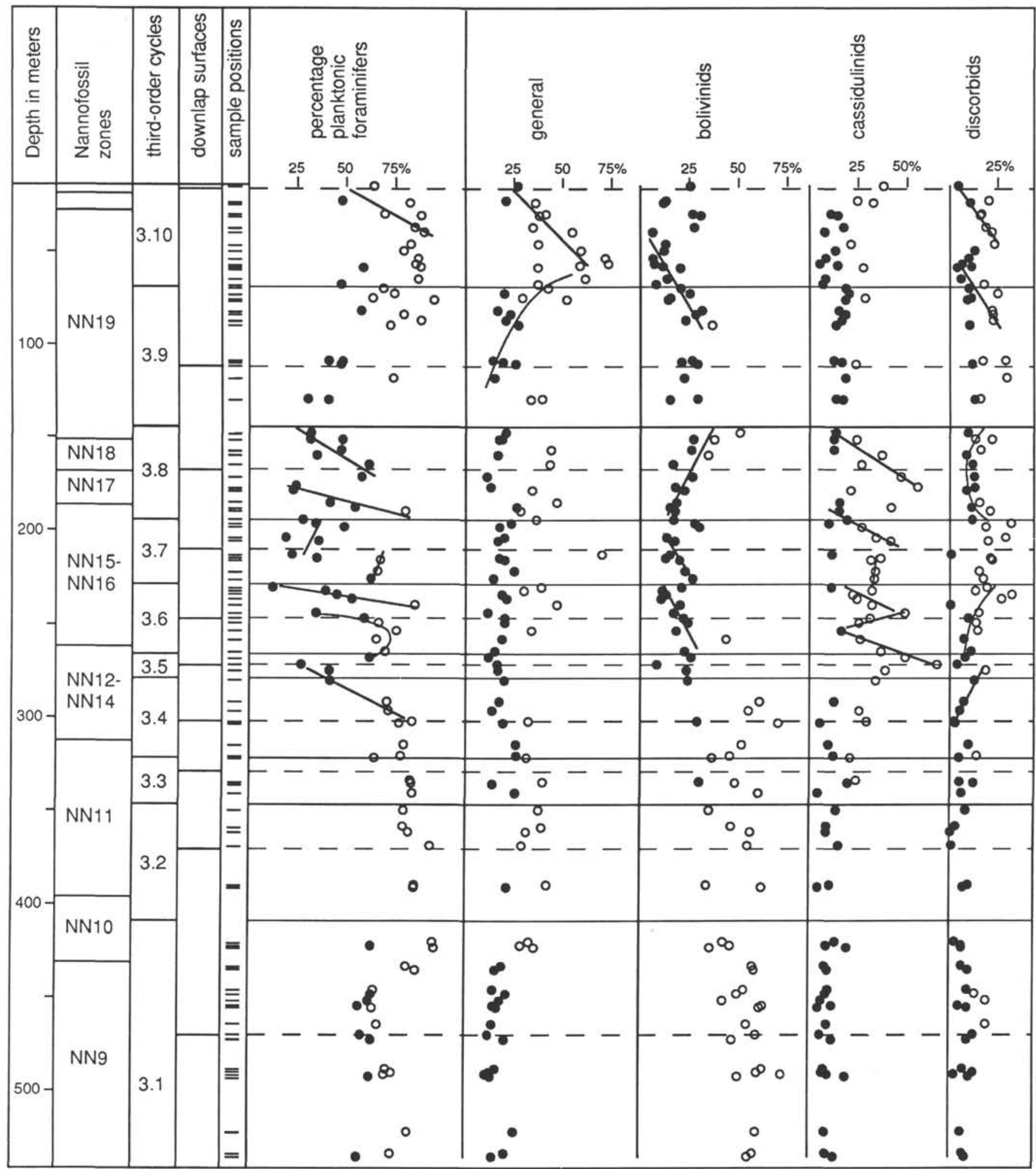

Figure 6. Estimates of foraminifer frequencies in the sand-sized fraction ( $>63 \mathrm{~m}$ ) of samples of carbonate turbidites from Site 767 , compared to third-order global cycles after Haq et al. (1988). Black dots in each column represent values that are less than the overall mean for the samples. Lines indicate short-term trends that were visually recognized. Horizontal lines indicate the position of a cycle termination, as determined from the nannofossil zonation, assuming constant rates of sedimentation within each zone. Percentages of benthic foraminifers are calculated with respect to the total benthic population; only the most frequent groups, which are all easily transported, are shown. "General" comprises disk-shaped tests, which are mostly juvenile. In their original habitat, bolivinids would be low-oxygen markers, cassidulinids have an outer shelf and deeper occurrence, while the epiphytic discorbids would represent shallow water. 


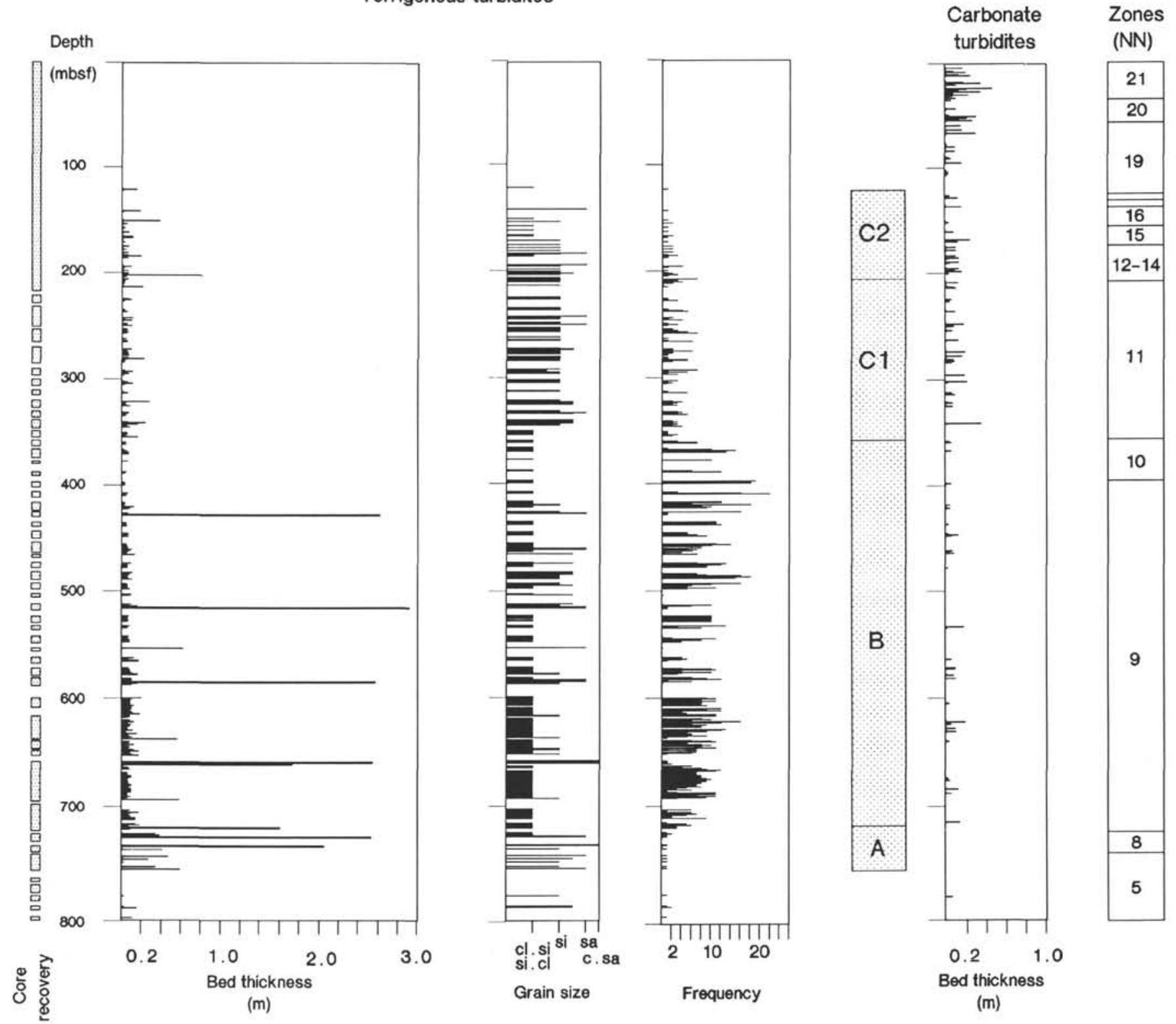

Figure 7. Turbidite systems, bed thickness distribution, grain-size distribution, and frequency distribution (turbidite layers) of terrigenous turbidites at Site 768, and bed thickness distribution of carbonate turbidites at Site 768.

In terms of Bouma (1962) sequences the beds consist of Td-e intervals and may be classified using the Stow and Piper (1984) scheme as T4-P and T6-P sequences. The base of the beds is usually sharp, but some layers show gradational contacts with underlying deposits, probably as a result of bioturbation of the thin silt layers. The silty intervals are overlain by undisturbed dark-gray or gray claystones. The upper part of the rhythms consists of greenish gray bioturbated claystones.

The bed thickness within this succession of thin turbidites shows a low variability (Fig. 7), whereas some changes in the frequency (turbidite layers $/ \mathrm{m}$ ) are observed (Fig. 8). In Cores 124-768C-11R, 124-768C-28R-124-768C-31R, and 124-768C$33 R-124-768 C-35 R$ there is an upward increase in the frequency of layers. In Core $124-768 \mathrm{C}-32 \mathrm{R}$ there is a decrease in frequency upward. In other cores, incomplete recovery does not allow a continuous description of the frequency.
There is little variation in the clast types in the thin-bedded turbidites of system B. Quartz and quartzose lithic fragments are dominant, with variable amounts of plant debris. Feldspar only occurs in trace amounts, usually as microcline, but plagioclase also occurs. Other minerals present include biotite, hornblende, and chlorite, all in trace amounts.

The thicker turbidite beds occur within Cores 124-768C$35 \mathrm{R}, 124-768 \mathrm{C}-32 \mathrm{R}, 124-768 \mathrm{C}-24 \mathrm{R}, 124-768 \mathrm{C}-17 \mathrm{R}$, and $124-$ $768 \mathrm{C}-8 \mathrm{R}$. Fig. 9 shows one of these beds within Core 124$768 \mathrm{C}-17 \mathrm{R}$. It is composed of a greenish gray sandstone grading upward into a gray clayey siltstone (Tb-e turbidite). In the lower half of the bed, plant debris is concentrated in laminae up to $1 \mathrm{~cm}$ thick. This lower layer is overlain by $10-$ to 20 -cm-thick graded sandstone to siltstone beds that show a thinning- and fining-upward trend. In this bed (and in similar, thick turbidites in Cores $124-768 \mathrm{C}-8 \mathrm{R}$ and $124-768 \mathrm{C}-24 \mathrm{R})$ the 

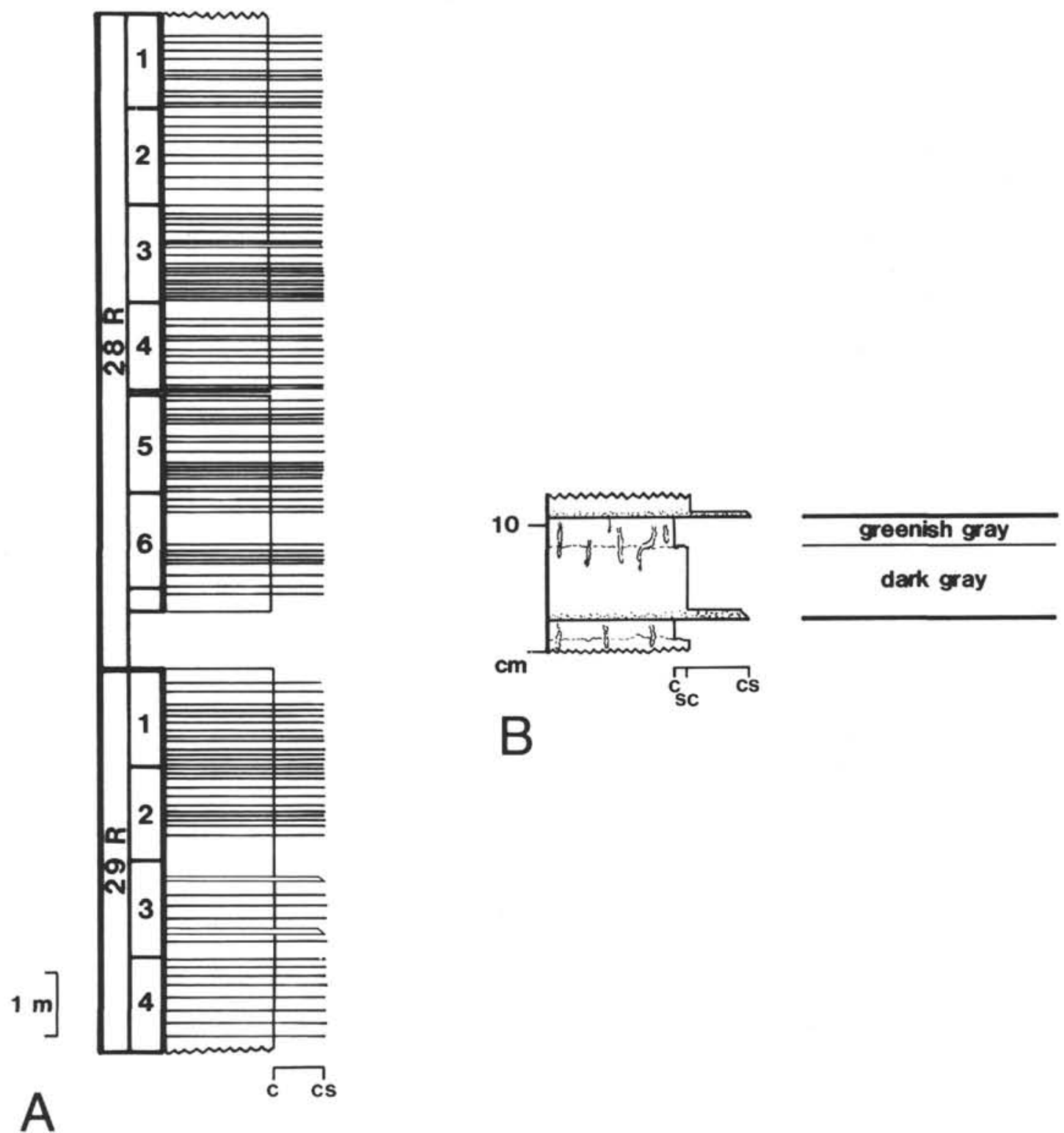

Figure 8. A. Representative interval of the thin-bedded facies of the turbidite system B, Site 768 (Cores 124-768C-28R and $-29 \mathrm{R}$ ). B. Detail showing the main characteristics of the turbidites. Each bed consists of a thin (average $1 \mathrm{~cm}$ ) dark-gray silty layer grading into dark-gray clays. In only a few cases does a faint parallel lamination occur in the basal interval. The hemipelagic intervals are thin. They consist of greenish gray bioturbated clays. The ratio of the turbidite layers/hemipelagic layers varies from $3: 1$ to $2: 1$. (c: clay; sc: silty clay; cs: clayey silt.)

quartz sand grains present appear to be quite distinct from those observed in the thinner turbidite beds; the surfaces of the grains are coated with a layer of opaque material (possibly iron oxide) and the grains have a more pitted and weathered appearance. Overall, these thick turbidite beds have a lower proportion of plant debris.

Another example of a thick turbidite bed with a different provenance is illustrated in Figure 10 . This $480-\mathrm{cm}$ thick bed (Core 124-768C-32R) consists of a coarse- to fine-grained volcanogenic sandstone composed mainly of volcanic lithic fragments, glass, and feldspar grains; dark-green mudstone clasts up to $1.5 \mathrm{~cm}$ across occur in the lower part of this bed. Sedimentary structures are represented by thick planar laminae in the lower part and convolute bedding associated with dish and pillar structures in the upper part. Scattered plant debris occurs in the lower part of this bed.

\section{System $C$}

This 244-m-thick system (Cores 124-768C-14H-124-768B$1 R$ ) is characterized by a succession of thin-bedded siliciclastic turbidites. The grain size ranges from sand to silty clay. One thicker $(80 \mathrm{~cm})$ sandy bed stands out within Core 124768B-22H: due to drilling disturbance it has a soupy structure and no sedimentary structures can be recognized.

System C is subdivided into two turbidite stages: the lower (NN11) is formed by a succession of thin-bedded siliciclastic turbidites with some sharp-based layers of calcareous clay. In the siliciclastic beds quartz grains (including strained and 


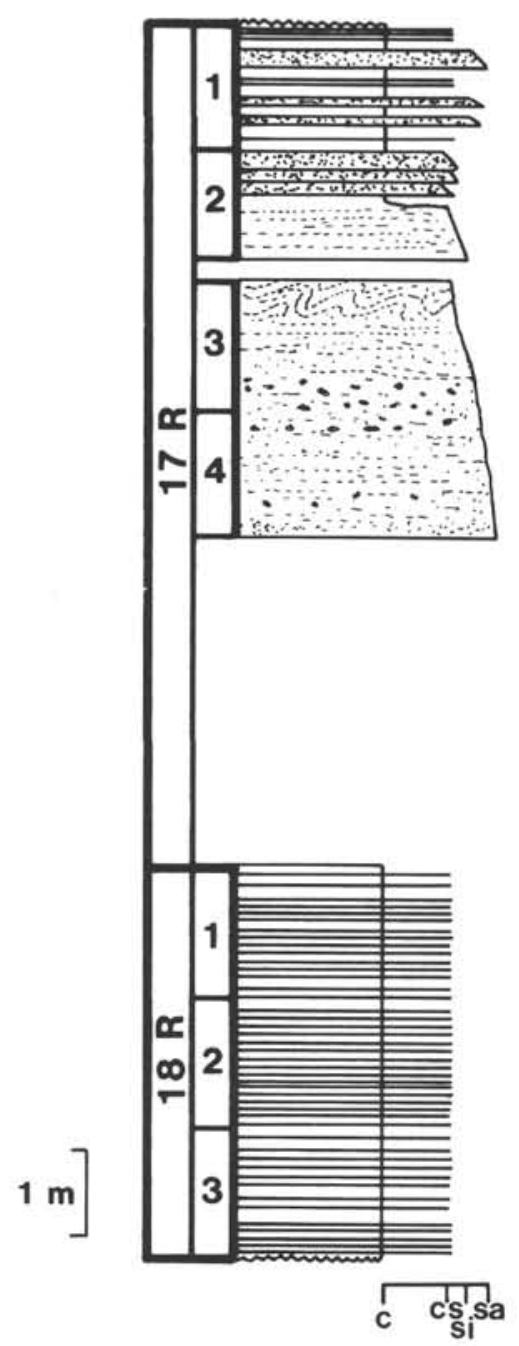

Figure 9. Representative interval of the turbidite system B, Site 768 (Cores 124-768C-17R and -18R). (c: clay; cs; clayey silt; si: silt; sa: sand.)

polycrystalline examples) and lithic fragments of quartzose rocks, some of which have a clear metamorphic fabric, are abundant. The grains are mostly sub-rounded, but angular and rounded grains also occur. Plant material is very common, including spores and pollen grains. Feldspar, biotite, and hornblende occur and there are rare but conspicuous grains of glaucophane. Fig. 11 shows a representative interval of this stage: it is characterized by dark-gray silt and silty sand to dark greenish gray silty clay rhythms up to $18 \mathrm{~cm}$ thick. The base of the bed is sharp and the silty and sandy intervals are planar laminated.

The upper part of system $\mathrm{C}(\mathrm{NN} 12$ to the lower part of NN19) consists of a few thin- to medium-bedded siliciclastic turbidites (Tc-e, Td-e) with more abundant calcareous layers. The composition of the siliciclastic material is the same as in the lower part of the system.

\section{Interpretation}

Turbidite system A shows the characteristics of the $\mathrm{C} 2$ to D1 facies of Mutti (1979) or the B2 (organized sands) to C2 (organized sand-mud couplets facies of Stow (1985) and Pickering et al. (1989) (Table 2). Within system B, the thinner beds are interpreted as D2 to D3 facies (Mutti, 1979) or as E2 facies

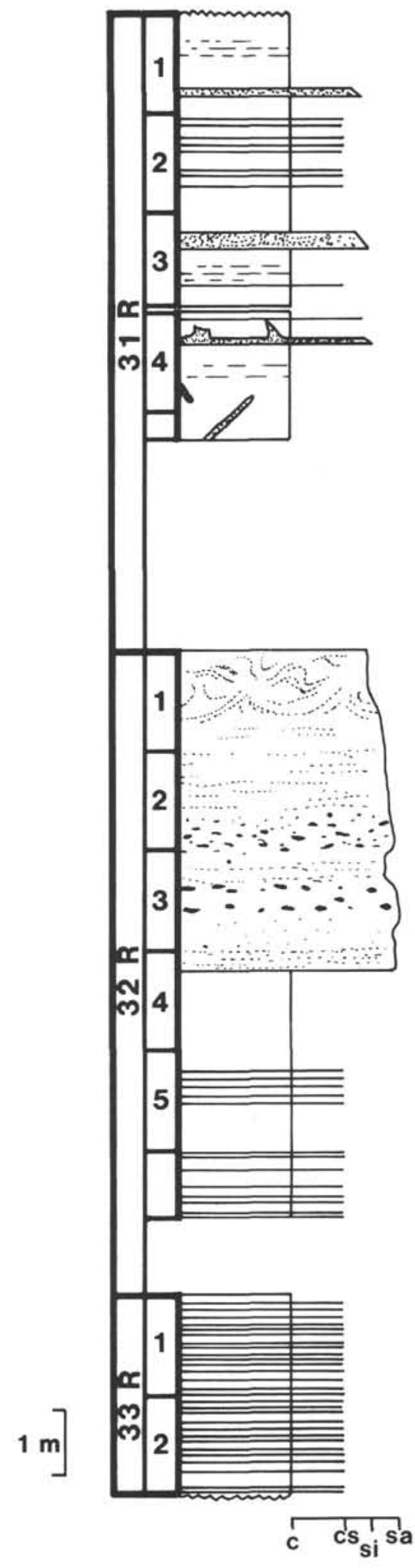

Figure 10. Volcaniclastic turbidite with plant debris, turbidite system B, Site 768 (Cores 124-768C-31R, -32R, and -33R). (c: clay; cs; clayey silt; si: silt; sa; sand.) 


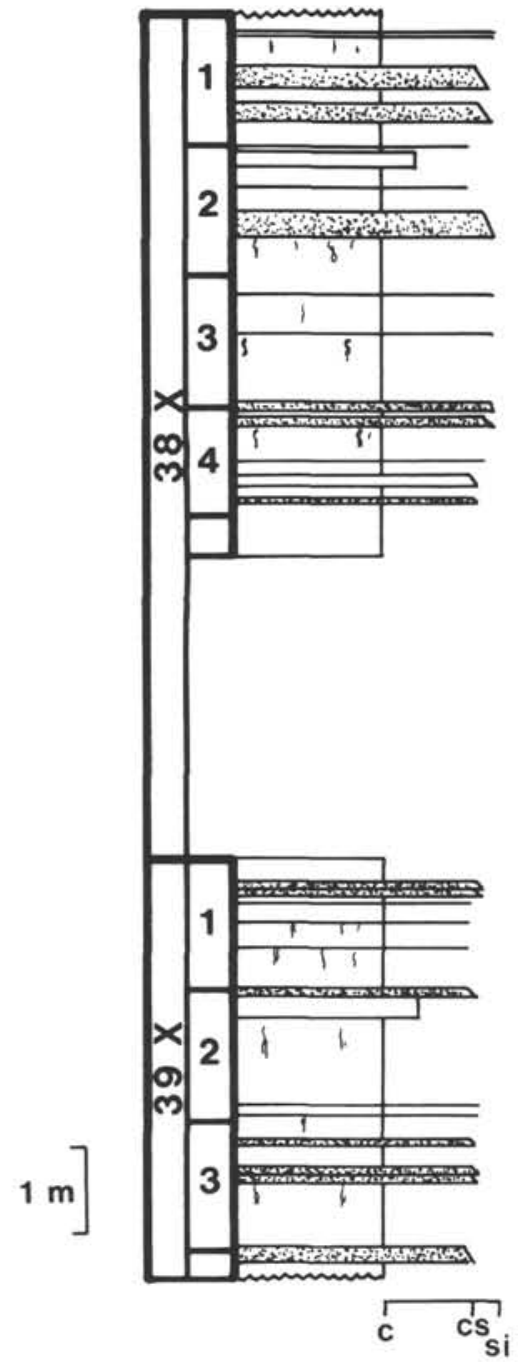

Figure 11. Representative interval of the turbidite system C1, Site 768 (Cores 124-768C-38X and -39X). (c: clay; cs: clayey silt; si: silt.)

(Stow, 1985; Pickering et al., 1989). The thick beds in system B are assigned to B1 facies (Mutti, 1979), which is characterized by the presence of water escape structures (see Fig. 9) and which corresponds to B2 facies of Stow (1985) or B1.1 facies of Pickering et al. (1989).

The turbidites of systems A and B are considered to have been deposited in a basin plain to fan fringe setting; similar deposits are described by Mutti and Ricci Lucchi (1972), Piper (1978), Van Vliet (1978), Stow and Piper (1984), and Stow (1985). These authors describe sediments lacking in any general megasequential arrangement and which are characterized by a uniform repetition of lithologies and the intercalation of some thicker beds. In the case of the Sulu Sea, the presence of thicker beds and an overall bimodal turbidite bed thickness can be attributed to separate provenance areas for the two groups of turbidites; the thinner turbidites were supplied from a source of "clean" quartz grains, whereas the thick turbidites were derived from a source where the quartz grains had undergone erosion and coating by opaque minerals, possibly in a subaerial environment.

Systems A and B in the Sulu Sea Basin are characterized on seismic sections by parallel reflectors (see Site 768 seismic stratigraphy chapter in Rangin, Silver, von Breymann, et al.,
1990) and are interpreted as type I system deposits (Mutti, 1985). Type I systems are characterized by continuous, roughly tabular geometries. The thin-bedded deposits of turbidite system $\mathrm{C1}$ show the characteristics of D3 facies of Mutti (1979) or D2 to E2 facies of Stow (1985) and Pickering et al. (1989). The upper part of turbidite system $\mathrm{C}$ shows similar characteristics. This turbidite system probably represents deposition within a type III system; the thicker sand bed in the lower part of this stage may be the expression of a thin type II system.

\section{Carbonate Turbidites}

Carbonate turbidites occur throughout the upper $790 \mathrm{~m}$ of sedimentary section at Site 768. In the lower part of this succession (NN15-NN18) they are up to $40 \mathrm{~cm}$ thick and consist of graded nannofossil marlstone beds that in most cases have a sharp base. Some of the marlstone layers are well indurated (see Betzler, this volume). In the upper part of the section the carbonate turbidites are thicker and more frequent.

The calcareous material is generally rather poorly preserved at this site and allows only a generalized analysis of the benthic foraminifers present. A shelf origin is indicated by the presence of skeletal debris and frequent benthic foraminifers in the lower part of the succession (Cores 124-768B-22H-124-768B-31X, upper Miocene to lowermost Pliocene) while the foraminifers from the younger part of the section (Pliocene and Pleistocene) give a deeper water signal (off the shelf). Benthic foraminifers are rare in most samples from the calcareous turbidites; they are extremely rare in the calcareous turbidites interbedded with the Pleistocene nannofossil marls. In terms of faunal content, the boundary between the lower and upper parts of the succession is transitional, suggesting that the source area either changed or shifted gradually through time.

\section{COMPARISON OF THE TURBIDITE COMPLEXES AT SITE 767 AND SITE 768}

\section{General Features}

The turbidite complexes and systems at Site 767 and Site 768 show a parallel evolution (Fig. 13). The onset of the main turbidite activity in both basins is at the transition from the middle to the upper Miocene.

In both basins the terrigenous turbidite complexes consist of two parts. The lower parts are characterized by sandy and thick-bedded successions showing an onlapping-fill pattern of small sub-basins (see chapters on seismic stratigraphy, Rangin, Silver, von Breymann, et al., 1990). The main difference between the two sites is the low turbidite frequency of the Celebes Sea in contrast to the high-frequency turbidite system of the Sulu Sea. This higher frequency results in a greater thickness of the upper Miocene at Site 768. The upper parts of the turbidite complexes are characterized by fine-grained and thin-bedded successions.

Turbidite deposition at Site 767 ceased during the early Pliocene. The topmost layers at this site consist of mixed volcaniclastic-siliciclastic material. At Site 768 the youngest siliciclastic turbidites occur around the Pliocene/Pleistocene Boundary.

\section{Sedimentary Breaks}

The turbidite complexes are subdivided by sedimentary breaks separating systems and stages with different style of turbidite deposition. (Figs. 12 and 13). Two types of breaks are differentiated:

1. The first type separates sandier, medium- to thickbedded turbidites from more silty, thin- to medium-bedded 
Table 2. Sedimentary structures and turbidite facies, Site 768.

\begin{tabular}{|c|c|c|c|c|c|c|}
\hline \multirow{2}{*}{$\begin{array}{l}\text { Systems } \\
\text { Site } 768\end{array}$} & \multirow[b]{2}{*}{ Description } & \multirow{2}{*}{$\begin{array}{l}\text { Bouma } \\
1962\end{array}$} & \multirow{2}{*}{$\begin{array}{l}\text { Stow \& Piper } \\
1984\end{array}$} & \multicolumn{3}{|c|}{ Facies } \\
\hline & & & & $\begin{array}{l}\text { Mutti } \\
1979 \\
\end{array}$ & $\begin{array}{l}\text { Stow } \\
1985 \\
\end{array}$ & $\begin{array}{c}\text { Pickering et al. } \\
1989\end{array}$ \\
\hline C & $\begin{array}{l}\text { thin to medium bedded } \\
\text { with planar and } \\
\text { ripple lamination } \\
\text { silty clays to sands }\end{array}$ & $T c-\theta, T d-\theta$ & & D3 & D2-E2 & D2-E2 \\
\hline B & $\begin{array}{l}\text { thin to thick bedded } \\
\text { with planar and } \\
\text { ripple lamination } \\
\text { silty clays to } \\
\text { coarse sands }\end{array}$ & $T b-\theta, T d-\theta$ & T4-P, T6-P & $\begin{array}{c}D 2-D 3 \\
\text { B1 }\end{array}$ & B2. E2 & B1.1. E2 \\
\hline A & $\begin{array}{l}\text { thin to thick bedded } \\
\text { with planar and } \\
\text { ripple lamination } \\
\text { sands }\end{array}$ & $\begin{array}{c}T b-\theta, T c-\theta \\
T d-e\end{array}$ & & D1-C2 & $\mathrm{B} 2-\mathrm{C} 2$ & $\mathrm{~B} 2-\mathrm{C} 2$ \\
\hline
\end{tabular}

Site 767

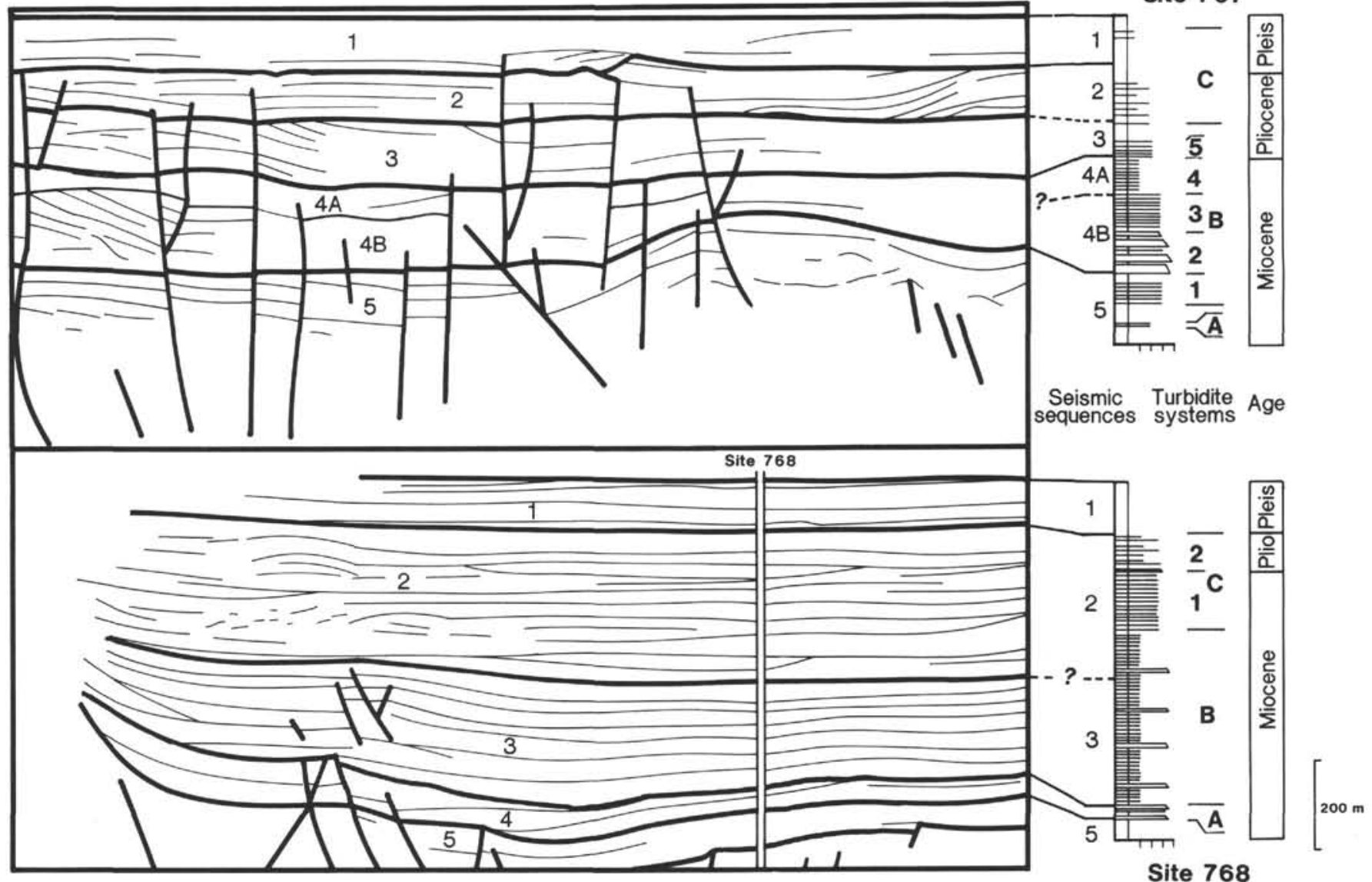

Figure 12. Comparison of the turbidite systems of Site 767 and 768 with the seismic sequences (c.f. chapter on seismic stratigraphy, Rangin, Silver, von Breymann, et al., 1990). At Site 767 the limit of the seismic sequence boundaries 1 and 2 may correspond to the thick carbonate turbidites at the limit of Zones NN18 and NN19. The limit of the seismic subsequences 4A and 4B may correspond to the flooding surface separating the turbidite systems B3 and B4. At Site 768 the limit between the seismic sequence boundaries 2 and 3 does not show any clear correspondence to a turbidite system limit. Based on the existence of subtle pinchouts, subsequences can be distinguished in seismic sequence 2 (see chapter on seismic stratigraphy, op. cit.). Note the infill pattern of the sub-basin in the seismic sequences 4 and 5 . 


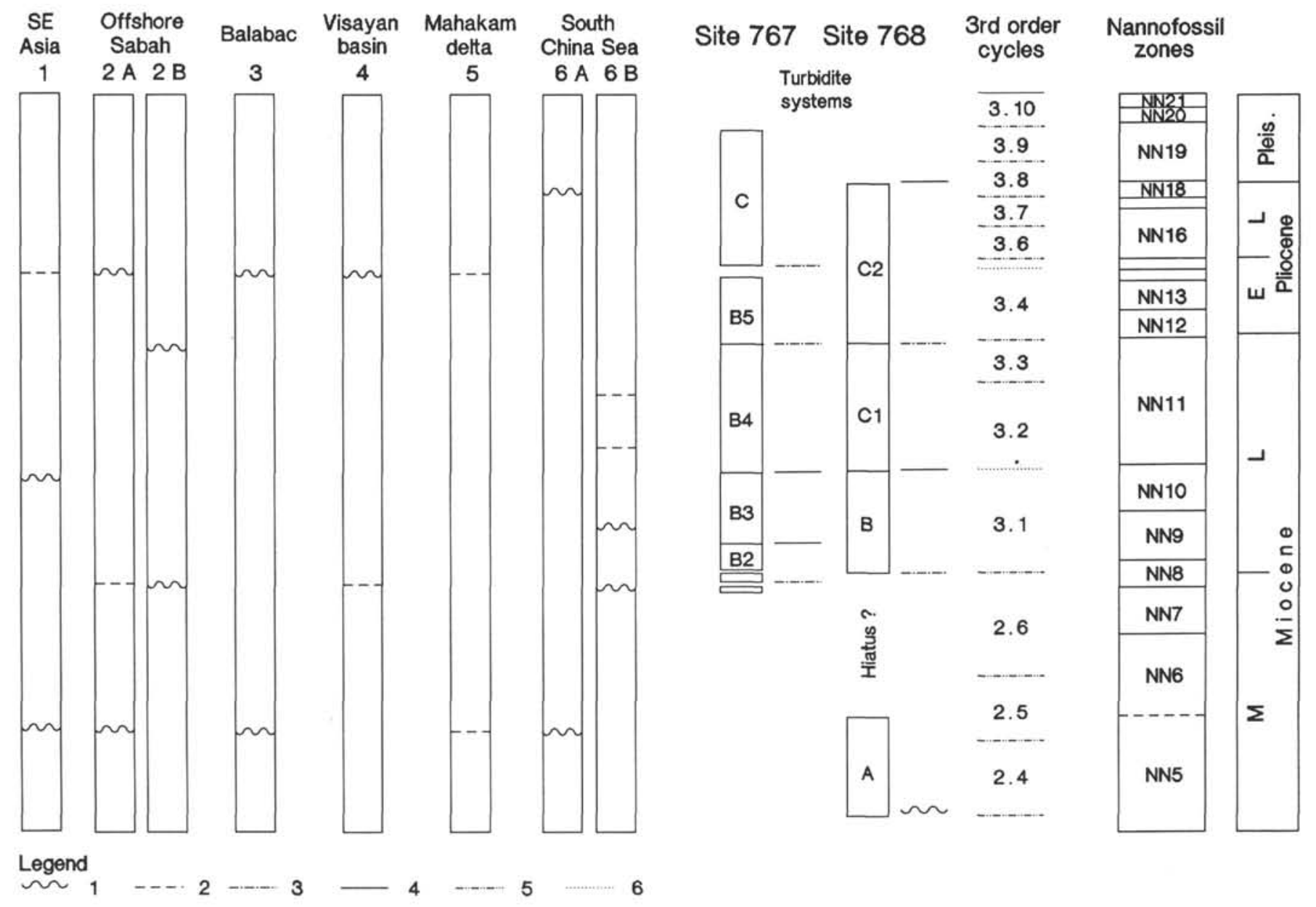

Figure 13. Comparison of the turbidite systems at Site 767 and Site 768 with Southeast Asian depositional cycles and unconformities and with the global third-order cycle limits (according to Haq et al. 1988). 1: Beddoes (1981) and Fulthorpe and Schlanger (1989); 2A: Hinz et al. (1989); 2B: Van Vliet and Schwander (1989); 3: Beddoes (1976); 4: Müller and Daniels (1981) and Müller et al. (1989); 5: Magnier et al. (1975); 6A: Rudolph and Lehmann (1989); 6B: Ru and Pigott (1986). Legend: 1: Unconformities in different Southeast Asian basins. 2: Boundaries which are defined as cycle limits by the authors. 3: Sedimentary breaks separating overlying "proximal" from underlying "distal" facies. These breaks are interpreted as limits of depositional sequences (sensu Vail, 1987). 4: Sedimentary breaks separating overlying "distal" from underlying "proximal" facies (e.g., horizons with glauconite at Site 768). 5: Type 1 cycle limits. 6: Type 2 cycle limits.

turbidites or pelagic to hemipelagic deposits (e.g., the base of system B2, Site 767 or the base of system C2, Site 768). The correspondence of some of these breaks with seismic sequence limits (Fig. 12) favors the interpretation that they correspond to limits of depositional sequences (sensu Vail, 1987) (see following section).

2 . The second type separates more silty, thin- to mediumbedded turbidites from sandier, medium- to thick-bedded successions (e.g., the base of system B3, Site 767 or the base of system C1, Site 768). This type of sedimentary break may correspond to flooding surfaces (sensu Vail 1987) and/or to type 2 sequence boundaries. Most of the breaks have the same age at both sites (Fig. 13).

\section{SIGNIFICANCE OF THE SEDIMENTARY BREAKS}

\section{Comparison with Adjacent Basins}

A comparison of the turbidite systems with the seismic units shows that some of the breaks can be correlated with seismic sequence boundaries (Fig. 12), which have a regional significance (Hinz et al., 1989).
Depositional sequences and depositional cycles for southeast Asia were defined by Beddoes (1981) and Fulthorpe and Schlanger (1989) (Fig. 13). In addition Beddoes (1976) reports sedimentary cycles from the southwestern Sulu Sea (Balabac). Regional unconformities offshore Sabah are described by Hinz et al. (1989) and Van Vliet and Schwander (1989). One boundary corresponds to the base of the Pliocene and one approximately to the boundary between the middle and late Miocene.

Müller and Daniels (1981) and Müller et al. (1989) describe two major unconformities from the Visayan Basin (Philippines). The lower one lies approximately at the boundary from the middle to the late Miocene, the upper one at the limit from the early to the late Pliocene. Magnier et al. (1975) report siliciclastic influxes and unconformities from the Mahakam Delta (middle/ late Miocene). The ages of sequence boundaries of platform carbonates of the South China Sea are given by Rudolph and Lehmann (1989): $10.5 \mathrm{Ma}$ (transition from the middle to the late Miocene); 8.2 Ma (late Miocene, transition from NN10); 6.3 Ma (late Miocene, NN11); and 5.5 Ma (late Miocene, NN11). Ru and Pigott (1986) mention two regional unconformities in the South 
China Sea. One in the mid-middle Miocene, the other at the transition from the Pliocene to the Quaternary.

Figure 13 shows that most of these unconformities can be correlated across the different basins. The unconformity at the middle-late Miocene transition (Sites 767 and 768) is recognized offshore Sabah, in the Visayan Basin and the South China Sea. The late Miocene break (the NN10 to NN11 Boundary) is recognized as a cycle boundary by Beddoes (1981). The unconformity (sequence boundary?) at the Miocene/Pliocene Boundary also appears offshore Sabah. The unconformity at the early to late Pliocene Boundary at Site 767 exists in Balabac, the Visayan Basin, and the Mahakam Delta. The boundary at the top of the turbidite system C at Site 768 only appears in the South China Sea.

As stated by Beddoes (1981), Hutchison (1989), and discussed by Müller and Daniels (1981), and by Müller et al. (1989), the age equivalence of these breaks favors an eustatic origin of the sedimentary cycles and the related unconformities of the Southeast Asian basins. However, in each of the basins modifications of the characteristics of the cycles occur due to different structural and plate tectonic settings (Beddoes, 1981; Hutchison, 1989). Other authors (e.g., Rangin et al., 1989) link the synchronism of hiatuses and major sedimentological changes to tectonic processes.

\section{Comparison with Global Third-order Cycle Limits}

As shown in Figure 13 most of the sedimentary breaks in the Celebes Sea and the Sulu Sea are age equivalent to second- and third-order cycle limits of the global sea-level chart of Haq et al. (1988). This fact supports the assertion that sea-level changes are an important control on the siliciclastic turbidite deposition in both basins.

The basal siliciclastic influx at Site 767 and the lower limit of the turbidite system B at Site 768 correspond to the lower boundary of the TB3 supercycle (Haq et al., 1988). This marked sea-level lowering at the middle/late Miocene Boundary is well documented in the Southeast Asian realm (Beddoes, 1981; Hutchison, 1989) and in several Australian basins (Loutit and Kennett, 1981).

The upper limit of stage 2 of system B at Site 767 is linked to a change in the type of turbidite deposition (a decrease in bed thickness and a decrease in grain size) and a change in the provenance of the siliciclastic material from a quartz-rich to a lithic-rich character. There is no corresponding change at Site 768 where the terrigenous turbidites are quartz-rich throughout the system.

The upper limit of system B3 (Site 767) and of system B (Site 768) correspond to a type 2 cycle boundary (upper limit of cycle 3.1). At Site 767 this limit is defined by a decrease in grain size, and at Site 768 by an increased glauconite content of the sediment (see visual core description). According to Vail (1987), this type of unconformity usually separates the deposits of shelf margin systems tract from the deposits of the underlying sequence in distal basinal settings. This interpretation of the turbidite system limit is supported by the biostratigraphic data (C. Müller, pers. comm., 1990). The nannofossil Zone NN10 is condensed at both sites.

The next eustatic signal that is recorded at both sites corresponds to the upper cycle limit of the cycle 3.3 (lower limit of system B5, Site 767; lower limit of system C2, Site 768). At both sites, this limit is reflected by an increase of the siliciclastic influx (thicker beds, coarser grain size).

In the upper part of the turbidite complexes the comparison of the turbidite systems with the global third-order cycles does not show a clear relationship. The increased glauconite content at the top of the system $\mathrm{C} 2$ can be correlated to the main flooding surface of the cycle 3.8 .

\section{Influence of the Tectonic Setting}

Beside the global sea-level signal, a strong tectonic control exists on the turbidite complexes. Compared to the thicker, high frequency system of the Sulu Sea, the succession of the Celebes Sea is thinner with a general trend of amalgamation of the thick-bedded layers. Apart from a different location within the two basin plain settings, this difference may reflect the high tectonic activity of the margins of the Sulu Sea (Rangin, 1989; K. Hinz, pers. comm., 1990) resulting in higher siliciclastic sediment input contrasting with quieter conditions in the Celebes Sea area. A similar process is also described by Pilkey (1987) from various basin plain settings.

In addition, the high tectonic activity results in the obscuration of a greater part of the third-order cycle boundaries predicted for this time interval. Such obscuring or enhancement of sequence boundaries is also known from deposits that formed in active foreland basins (e.g., Luterbacher et al., in press).

Tectonic activity is also likely to have exerted a strong control on the pathways of sediment supply into the basins. The tectonic controls on the supply of material to both the Celebes and Sulu Sea are discussed in the section on provenance below.

\section{PROVENANCE OF SILICICLASTIC TURBIDITES}

In the absence of any palaeocurrent data from the turbidite complexes at Sites 767 and 768 , provenance can only be determined on the basis of the petrology of the detrital components. Detailed studies of the rock types that would have been exposed in the likely source areas of Borneo to the southwest and the Philippine archipelago to the north and east would be necessary to make more precise determinations of the provenance of the clastic components of the turbidites.

At least three different types of source of clastic detritus are indicated by the composition of the siliciclastic turbidites in the Celebes Sea at Site 767. The first two stages of turbidite system B are dominated by quartz and quartz-lithic clasts with abundant plant debris. The compositional maturity of these sands suggests that they were reworked from a shallow marine/continental depositional environment where there was abundant vegetation. A change in source area is indicated by the paucity of quartz in the upper stages of system B and the relative abundance of chert and other rock fragments. The exact source of this material cannot be established without detailed studies of the landmasses surrounding the Celebes Sea, but some Tertiary sedimentary units on Sabah (Borneo) contain a very high proportion of chert fragments (B. Clennell, pers. comm., 1990). If most of the quartz grains in the lower part of system B were derived from the continental basement areas of Mindanao, their absence in the higher parts of the sequence can be attributed to early stages in the development of the Cotobato Trench (which lies between Mindanao and Site 767). A third source of siliclastic material appears to have been one or more volcanic terrains that supplied material to most of the siliciclastic turbidites. In the absence of quartzose detritus, volcanogenic material (plagioclase feldspars, biotite, hornblende, and volcanic lithic fragments) are the principal components of the turbidites, e.g., in system C at Site 767. The Sulu Islands, to the northwest of the Celebes Sea, may have been one of the volcanic source areas.

The bulk of the siliciclastic turbidites at Site 768 in the Sulu Sea are rich in quartz, quartz-lithic grains, and plant fragments. The compositions are strikingly similar to the turbidites of the lower part of system B in the Celebes Sea, Site 767 , which are partly coeval, but in the absence of detailed studies of the nature of the possible source areas we cannot 
conclude that the Celebes and Sulu Seas shared a common source of quartz-rich detritus in the early and middle Miocene. A second source of quartz-rich detritus in the Sulu Sea is indicated by the occurrence in system B at Site 768 of considerably thicker turbidites that contain more abraded and coated grains of quartz. These thicker turbidites are interbedded with the more common, thinner turbidites that contain "cleaner" quartz grains, indicating that there were two separate but coeval supplies of turbiditic detritus to this part of the Sulu Sea Basin during this period. Small amounts of volcanogenic detritus, principally plagioclase feldspar, biotite, and hornblende, occur throughout the turbidite complex. Rare grains of glaucophane in system B at Site 768 may be traceable to a specific rock unit in one of the surrounding terranes, but such a link has yet to be established.

The cessation of terrigenous turbidite deposition at Site 768 in the Pliocene may be related to the development of the Negros Trench on the northeast side of the Sulu Sea Basin. Piston cores from the accretionary wedge of the Negros/Sulu Trench reveal that siliciclastic turbidite deposits are common (Kudrass et al., 1989). This suggests that siliclastic material from the Philippine Archipelago that was formerly deposited as turbidites in the Sulu Sea Basin is currently trapped as a result of the development of the trench at the basin margin $(\mathrm{H}$. R. Kudrass, pers. comm., 1990).

\section{SUMMARY}

\section{Siliciclastic Turbidites}

The sediments cored at Sites 767 and 768 provide the possibility of comparing age-equivalent turbidite complexes in two adjacent, but different basin settings in the Celebes and Sulu seas.

The sedimentary breaks in both turbidite complexes have the same age. The time equivalence of the sedimentary breaks with sequence boundaries in adjacent sedimentary basins and with global third-order cycle limits suggest a regional significance of these unconformities.

The basal terrigenous influx in both basins corresponds to the lower limit of the TB3 supercycle (Haq et al., 1988). The lower limits of the cycles 3.2 and 3.4 are recognized at both sites, and the lower limit of cycle 3.6 is recorded at Site 767. The top of the turbidite system $\mathrm{C}$ at Site 768 corresponds to the main flooding surface of cycle 3.8 .

The high tectonic activity in the Southeast Asian realm, especially in the Sulu Sea (Rangin, 1989), results in:

1. Obscuration of predicted third-order cycle limits.

2. Differences of the thicknesses of turbidite systems that have the same age (different sediment influxes).

3. Cutting-off of the terrigenous sedimentary input as a response to changes in basin configuration.

\section{Carbonate Turbidites}

The long-term changes in the carbonate turbidites at Site 767 can also be related to major sea-level events, just as in the siliciclastic turbidites. The lower frequencies of benthic foraminifers and absence of skeletal debris in the sediments of the late Miocene Zones NN10 and NN11, which was a period of predominantly high global sea level, can be interpreted as starvation of shelf-derived material compared to the deeper parts of the section. In this, the carbonate system appears comparable to the siliciclastic turbidites of Site 768 in the Sulu Sea, which show a starvation of the same age. The renewed input of shallow derived material close to the top of the early Pliocene Zones NN12 and NN14 corresponds to the major fall of sea level at the base of the cycle 3.6.
The interpretation of short-term changes is less straight forward. The formation of carbonate turbidites is a function of erosion as well as of production. A carbonate platform would have a higher growth potential during times of high sea level and shed more material (Droxler and Schlager, 1985; Reymer et al., 1988). On the other hand, magnitude of calciclastic turbidites can be high in times of initial sea-level lowering (Shanmugam and Moiola, 1984). At Site 767 the long-term changes of the carbonate turbidites are comparable to the evolution of the siliciclastic turbidite systems, in that shelfderived material appears to be more important during sealevel lowstands. This fact suggests that erosion of shelf deposits played an important role in formation of the carbonate turbidites.

The short-term fluctuations in the thickness and frequency of the Pliocene turbidites and their foraminifer frequencies are at a scale that is comparable to that of the third-order sea-level cycles. However, a one-to-one correlation is not obvious. It seems likely that the interplay of erosion and production changes, in combination with a tectonic overprint, produced more complex pattern than could be recognized at the scale of the samples. However, there is some indication that two intervals with progressively increasing amounts of shallowwater material (benthic foraminifers) and increasing energy (thicker turbidites) occur in each third-order cycle. The lower of these coarsening upward sequences might be related to a prograding lowstand fan, the upper to material shed from a highstand prograding shelf.

\section{ACKNOWLEDGMENTS}

The authors thank H. P. Luterbacher for the critical reading of a version of this manuscript, $K$. Hinz and $H$. Kudrass for helpful suggestions, and P. Zügel and W. Ries for technical assistance. C. B. acknowledges the financial support of the Deutsche Forschungsgemeinschaft, A.J.N. acknowledges the support of the Dutch Stichting Onderzoek der Zee, and G.J.N. acknowledges the financial support of the U.K. Natural Environment Research Council. We thank D.J.W. Piper and M. B. Underwood for reviewing the manuscript, and their helpful comments.

\section{REFERENCES}

Beddoes, L. R., 1976. The Balabac Sub-Basin, Southwestern Sulu Sea, Philippines. Seapex Program, Offshore South East Asia Conf. Pap., 15:1-22.

1981. Hydrocarbon plays in Tertiary basins of southeast Asia. Energy, 6:1141-1163.

Bouma, A. H., 1962. Sedimentology of Some Flysch Deposits: Amsterdam (Elsevier).

Droxler, A. W., and Schlager, W., 1985. Glacial versus interglacial sedimentation rates and turbidite frequencies in the Bahamas. Geology, 13:799-802.

Fulthorpe, C. S., and Schlager, S. O., 1989. Paleo-oceanographic and tectonic settings of early Miocene reefs and associated carbonates offshore Southeast Asia. AAPG Bull., 73:729-756.

Gorsline, D. S., 1984. A review of fine-grained sediment origins, characteristics, transport and deposition. In Stow, D.A.V., and Piper, D.J.W. (Eds.), Fine-grained Sediments: Deep-water Processes and Facies: Oxford (Blackwell), 17-34.

Haq, B. U., Hardenbol, J., and Vail, P. R., 1988. Mesozoic and Cenozoic chronostratigraphy and cycles of sea-level change. In Wilgus, C., et al., (Eds.), Sea-Level Change-An Integrated Approach. Soc. Econ. Paleontol. Mineral. Spec. Publ., 42:71-108.

Hinz, K. Fritsch, J., Kempter, E.H.K., Manaf Mohammad, A., Meyer, J., Mohamed, D., Vosberg, H., Weber, J., and Benavidez, J., 1989. Thrust tectonics along the north-western continental margin of Sabah/Borneo. Geol. Rundsch., 78:705-730.

Hutchison, C. S., 1989. Geological evolution of South-East Asia. Oxford Monogr. Geol. Geophys., No. 13. 
Jervey, M. T., 1988. Quantitative geological modelling of siliciclastic rock sequences and their seismic expression. Spec. Publ. Soc. Econ. Paleontol. Mineral., 42:48-69.

Klein, G. deV., 1984. Relative rates of tectonic uplift as determined from episodic turbidite deposition in marine basins. Geology, $12: 48-50$.

Kolla, V., and Macurda, D. B., 1988. Sea-level changes and timing of turbidity-current events in deep-sea fan systems. Spec. Publ., Soc, Econ. Paleontol. Mineral., 42:381-392.

Kudrass, H. R., Beiersdorf, H., Berner, U., Block, M., Dumke, I., Faber, E., Frishe, A., Hansen, D., Muller, P., Quadfasel, D., Steinmann, D., Vollbrecht, R., Weiss, W., and Kreuzer, H., 1989, Geological, geochemical, and geothermal investigations in the Sulu Sea/Philippines. Rept. Bundesanst. Geowiss. Rohst., Hannover.

Kuhn, G., and Meischner, D., 1988. Quaternary and Pliocene turbidites in the Bahamas, Leg 101, Sites 628, 632, and 635. In Austin, J. A., Jr., Schlager, W., et al., Proc. ODP, Sci. Results, 101: College Station, TX (Ocean Drilling Program), 203-212.

Loutit, T. S., and Kennett, J. P., 1981. New Zealand and Australian Cenozoic sedimentary cycles and global sea level changes. $A A P G$ Bull., 65:1586-1601.

Luterbacher, H., Eichenseer, H., Betzler, C., and van den Hurk, A., in press. Carbonate-siliciclastic depositional systems in the Paleogene of the south Pyrenean foreland basin: a sequence-stratigraphic approach. In Macdonald, D. (Ed.), Sea level changes at active plate margins: processes and products. Int. Assoc. Sediment. Spec. Publ.

Magnier, P., Oki, T., and Witoelar Kartaadiputra, L., 1975. The Mahakam Delta, Kalimantan, Indonesia. 9th World Petrol. Congr., 2:239-250.

Mammerickx, J., Fisher, R. L., Emmel, F. J., and Smith, S. M., 1976. Bathymetry of the East and Southeast Asian Seas. Geol. Soc. Am. Map and Chart Ser., MC-17.

Mascle, A., and Biscarrat, P. A., 1978. The Sulu Sea: a marginal basin in Southeast Asia. In Watkins, J. S., Montadert, L., and Dickerson, P. W. (Eds.), Geological and Geophysical Investigations of the Continental Margins: AAPG Mem., 29:373-381.

Mitchum, R. M., 1985. Seismic stratigraphic expression of submarine fans. AAPG Mem., 39:117-136.

Müller, C., and von Daniels, C. J., 1981. Stratigraphical and paleoenvironmental studies (Oligocene-Quaternary) in the Visayan basin, Philippines. Newsl. Stratigr., 10:52-64.

Müller, C., von Daniels, C. H., Cepek, P., Gramann, F., Bausa, J. G., and de Leon, M. M., 1989. Biostratigraphy and paleoenvironmental studies in the Tertiary of the Visayan Basin, Philippines. Geol. Jahrb., 70:89-145.

Mutti, E., 1977. Distinctive thin-bedded turbidite facies and related depositional environments in the Eocene Hecho Group (south central Pyrenees, Spain). Sedimentology, 24:107-132.

1979. Turbidites et cones sous-marins profonds. 3 me Cycle Romand Sciences de la Terre, Fribourg. Sedimentation detritique: $355-419$.

1985. Turbidite systems and their relation to depositional sequences. In Zuffa, G. G. (Ed.), Provenance of Arenites: Dordrecht (D. Reidel), 65-93.

Mutti, E., and Normark, W. R., 1987. Comparing examples of modern and ancient turbidite systems: problems and concepts. In Leggett, J. K., and Zuffa, G. G. (Eds.), Marine Clastic Sedimentology. London (Graham \& Trotman), 1-38.

Mutti, E., and Ricci Lucchi, F., 1972. Le torbiditi del l'Appennino settentrional: introduzione all'analisi de facies. Mem. Soc. Geol. Ital., 11:161-199.

1975. Turbidite facies and facies associations. 9th Int Sedimentol. Congr., Field Trip Guidebook A-11, 21-36.

Pickering, K. T., Hiscott, R. N., and Hein, F. J., 1989. Deep Marine Environments: Clastic Sedimentation and Tectonics: London (Unwin Hyman).

Pilkey, O. H., 1987. Sedimentology of basin plains. In Weaver, P.P.E., and Thompson, J. (Eds.), Geology and Geochemistry of Abyssal Plains. Geol. Soc. Spec. Publ. London, 31:1-12.

Piper, D.J.W., 1978. Turbidite muds and silts on deep sea fans and abyssal plains. In Stanley, D. J., and Kelling, G. (Eds.), Sedimen- tation in Submarine Canyons, Fans, and Trenches: Stroudsberg, PA (Dowden, Hutchinson and Ross), 163-176.

Posamentier, H. W., and Vail, P. R., 1988. Eustatic control on clastic deposition II. Sequence and systems tracts models. In Wilgus, C. K., Hastings, B. S., Kendall, C. G., Posamentier, H. W., Ross, C. A., and Van Wagoner, J. C. (Eds.), Sea-level Changes: An Integrated Approach. Spec. Publ. Soc. Econ. Paleontol. Mineral. 42:125-154.

Rangin, C., 1989. The Sulu Sea, a back-arc basin setting within a Neogene collision zone. Tectonophysics, 161:119-154.

Rangin, C., Müller, C., and Porth, H., 1989. Neogene geodynamic evolution of the Visayan region. Geol. Jahrb., 70:7-27.

Rangin, C., Silver, E., and Leg 124 Scientific Party, 1989. Forages dans les bassins marginaux du SE asiatique: résultats préliminaires du Leg 124 (Ocean Drilling Program). C. R. Acad. Sci. Ser. 2, 309:1333-1339.

Reymer, J.J.G., Schlager, W., and Droxler, A. W., 1988. Site 632: Pliocene-Pleistocene sedimentation cycles in a Bahamian basin. In Austin, J. A., Jr., Schlager, W., et al., Proc. ODP, Sci. Results, 101: College Station, TX (Ocean Drilling Program), 213-220.

$\mathrm{Ru}$, K., and Pigott, J. D., 1986. Episodic rifting and subsidence in the South China Sea. AAPG Bull., 70:1136-1155.

Rudolph, K. W., and Lehmann, P. J., 1989. Platform evolution and sequence stratigraphy of the Natuna platform, South China Sea. Spec. Publ. Soc. Econ. Paleontol. Mineral., 44:353-361.

Shanmugan, G., and Moiola, R. J., 1984. Eustatic control of calciclastic turbidites. Mar. Geol., 56:273-278. 1988. Submarine fans: characteristics, models, classification, and reservoir potential. Earth Sci. Rev., 24:383-428.

Shanmugan, G., Moiola, R. J., and Damuth, J. E., 1985. Eustatic control of submarine fan development. In Bouma, A. H., Normark, W. R., and Barnes, M. E. (Eds.), Submarine Fans and Related Turbidite Systems: New York (Springer-Verlag), 23-28.

Stanley, D. J., and Maldonado, A., 1981. Depositional models of fine-grained sediments in the Western Hellenic Trench, eastern Mediterranean. Sedimentology, 28:173-290.

Stow, D.A.V., 1985. Deep-sea clastics: where are we and where are we going? In Brenchley, P. J., Williams, B.P.J. (Eds.), Sedimentology: Recent Developments and Applied Aspects. Geol. Soc. Spec. Publ. London, 18:67-94.

Stow, D.A.V., Howell, D. G., and Nelson, C. H., 1985. Sedimentary, tectonic, and sea-level controls. In Bouma, A. H., Normark, W. R., and Barnes, N. E. (Eds.), Submarine Fans and Related Turbidite Systems: New York (Springer-Verlag), 15-22.

Stow, D.A.V., and Piper, D.J.W., 1984. Deep-water fine-grained sediments: history methodology and terminology. In Stow, D.A.V., and Piper, D.J.W. (Eds.), Fine-Grained Sediments: Deep-Water Processes and Facies. Geol. Soc. Spec. Publ. London, 15:611-646.

Vail, P. R., 1987. Part 1: seismic stratigraphic interpretation proceedure. AAPG Stud. Geol., No. 27, 1:1-10.

van Marle, L. J., van Hinte, J. E., and Nederbragt, A. J., 1987. Plankton percentage of the foraminiferal fauna in seafloor samples from the Australian-Irian Jaya continental margin, Eastern Indonesia. Mar. Geol., 77:151-156.

Van Vliet, A., 1978. Early Tertiary deep-water fans of Guipuzcoa, Northern Spain. In Stanley, D. J., and Kelling, G. (Eds.), Sedimentation in Submarine Canyons, Fans and Trenches: Stroudsburg, PA (Dowden, Hutchinson, \& Ross), 190-209.

Van Vliet, A., and Schwander, M. M., 1989. Stratigraphic interpretation of a regional seismic section across the Labuan syncline and its flank structures, Sabah, north Borneo. AAPG Stud. Geol., No. 27, 3:163-167.

Wright, R. G., 1977. Planktonic-benthonic ratio in foraminifera as a palaeobathymetric tool. Quantitative evaluation. Annual Conv. AAPG and Soc. Econ. Paleontol. Mineral., 65. (Abstract)

Date of initial receipt: 4 June 1990 Date of acceptance: 18 December 1990 Ms 124B-137 